\title{
THE IDENTIFICATION OF LANDSLIDE-PRONE AREAS AND HOW TO SOLVE IN SUNGAI PINYUH SUB-DISTRICT MEMPAWAH REGENCY
}

\author{
Rahmah $^{1}$, Sulistyarini ${ }^{2}$, Ludovicus Manditya Hari Christanto ${ }^{3}$ \\ ${ }^{123}$ Geography Education, Faculty of Teacher Training and Education \\ Universitas Tanjungpura Pontianak \\ E-mail: rahma150197@gmail.com
}

\begin{abstract}
This study aims to determine the spatial distribution of landslide vulnerability and its mitigation in Sungai Pinyuh District Mempawah District. This type of research is qualitative. Data collection methods are observation and documentation. The data analysis technique used is descriptive analysis, using GIS (Geographic Information System) 10.1 application with weighted tiered quantitative overlay modeling. The results of this study indicate that: 1) The level of landslide susceptibility in Sungai Pinyuh District consists of 3 classes: low (not prone), moderate (prone) and high (very vulnerable). (a) Areas that are not vulnerable are spread throughout the villages in Sungai Pinyuh District. (b) Areas with moderate level of vulnerability (vulnerable) are spread in Galang Village (0.24\%), Nusapati Village (1.74\%), Peniraman Village (3.22\%), Sungai Pinyuh Village (1.18\%), and Sungai Purun Kecil Village $(0.11 \%)$. (c) Areas with a high level of vulnerability (very vulnerable) are only found in Peniraman Village, which has 223 ha or 1.15\% of the total area of Sungai Pinyuh District. 2) the location of the observation points shows that there are seven points selected, including six points with a level of vulnerability and one point with a very vulnerable level, then of the seven have different land use characteristics.
\end{abstract}

Keywords: Landslide, Prone, Landslide Management

\section{A. INTRODUCTION}

Landslide is one form of geosphere phenomenon, because natural disaster is a disaster that occurs due to natural phenomena that greatly affect human life. Geography is an interdisciplinary field of research that makes it possible to make progress in mitigating and adapting to natural hazards by analyzing the multifaceted characteristics of potential vulnerabilities Fuchs et al (in Gillard, 2016: 21). Geography study is very much needed in the matter of disaster, because disaster geography places more emphasis on the concept of spatial as a disaster management effort, where spatial information in the form of hazard map, vulnerability map, risk map and hazard map of a disaster is very much needed by the community. as a response, in order to minimize the impact caused by disasters that occur, especially landslides. According to Sitorus (2006: 37) Landslide is a form of erosion in which transportation or removal of land occurs at a relatively short time in a very large volume (amount). Nugroho (in Faizana et al, 2014: 225) said that landslide events 
can occur due to land instability that is generally caused by human activity. Massive deforestation, exposure from the soil rock system - facilitates direct entry of rainwater and associated increases in pore pressures causing landslide. Beaty (in Ramsamy 2016: 70). In addition, factors of seismicities, rainfall and anthropogenic activities serve as triggers for the landslide. Hutchinson (in Muthukumar 2017: 68). so that with these problems need mitigation efforts.

Sutikno (2002: 57) said disaster management (disaster management) is all planned and organized efforts that are realized in a series of activities carried out to minimize part or all of the hazards and losses from disasters, and avoid the risk of potential disasters that will occur, so that the con sequences the consequences can be reduced, or even eliminated.

Therefore the need for attention to landslides, so as not to cause property losses and the safety of the people who live in areas prone to landslides. According to Anandan (2008: 92) said that the effort that can be done as a solution to overcome the problem of landslides is to conduct research in the form of mapping landslide-prone areas, by using GIS studies to provide an overview of landslide-prone areas, which aims to determine efforts to prevent landslides according to the level of vulnerability.

In line with the development of geography, one of the appropriate geographic approaches to study geographic phenomena related to disaster problems is to use a spatial approach, to study the spatial distribution of landslide hazard levels and mitigation efforts in Sungai Pinyuh District Mempawah District.

Based on the hazard map which is used as one of the bases for the preparation of the spatial plan of Mempawah Regency in 2014 to 2034, which contains information related to the distribution of disasters in Mempawah Regency. Disaster-prone maps show the distribution of land fire disasters almost occurred in several upstream and downstream sub-districts of Mempawah Regency, while the potential distribution of land fire-prone disasters in Mempawah Regency, namely: Sadaniang District, Toho District, Sungai Kunyit District, District of Mempawah Timur, and Sungai Pinyuh District with the highest number of land fire distribution points compared to other districts.Furthermore, for the distribution of potential flood disasters spread in the District which is located close to the coast which includes: Sungai Kunyit District, Mempawah Hilir and Mempawah Timur Districts, Sungai 
Pinyuh District, Segedong District and Siantan District. The distribution of landslide- prone potential is only spread in 2 (two) subdistricts in Mempawah Regency, namely Sadaniang District and Sungai Pinyuh District.

Sungai Pinyuh District is a district located between 0011 'North Latitude and 0025' North Latitude and 108058 'East Longitude and 109013' East Longitude. It borders north with Anjongan District, borders south with Natuna Sea, borders west with Mempawah Timur District and east borders with Segedong District and Landak Regency. Sungai Pinyuh subdistrict is determined as one of the districts that has the potential for landslides.

Landslide events in the Pinyuh River District occur because of the morphological conditions of the hilly land, which overall characteristics of landslide prone areas have similarities between villages in the Pinyuh River District, but the potential for vulnerability to landslide hazards from each village that distinguishes them, things This is because the slope in each village has different variations ranging from ramps $(0 \%-8 \%)$ to steep (>40\%).

In addition, landslides occur because they are supported by the presence of excavation $\mathrm{C}$ material, which causes the steep slope walls and steep loss of vegetation / land cover, as well as supported by the use of land and the activities of the community that are less appropriate in utilizing and managing land in landslide prone areas. Potential for landslide hazard is strengthened by the existence of landslide data in Sungai Pinyuh District obtained from the Regional Disaster Management Agency (BPBD) of Regency of Mempawah \& Borneo Tribun Mempawah. The following are landslide data in Sungai Pinyuh District.

Table 1. Landslide Disaster Data

\begin{tabular}{|c|c|c|}
\hline $\begin{array}{l}\text { Village } \\
\text { and } \\
\text { Time }\end{array}$ & Material losses & Victim \\
\hline $\begin{array}{l}\text { Peniraman } \\
\text { (1991) }\end{array}$ & $\begin{array}{l}\text { Hundreds of houses } \\
\text { were badly } \\
\text { damaged }\end{array}$ & $\begin{array}{l}9 \text { people } \\
\text { killed }\end{array}$ \\
\hline $\begin{array}{l}\text { Peniraman } \\
(2003)\end{array}$ & $\begin{array}{l}10 \text { damaged houses } \\
\text { buried in the ground }\end{array}$ & $\begin{array}{l}10 \text { people } \\
\text { killed }\end{array}$ \\
\hline $\begin{array}{l}\text { Peniraman } \\
(2010)\end{array}$ & $\begin{array}{l}5 \text { houses severely } \\
\text { damaged, } 1 \text { was } \\
\text { slightly danaged, } \\
\text { hundreds of houses, } \\
\text { schools anda } \\
\text { mosques submerged } \\
\text { in mud. }\end{array}$ & - \\
\hline $\begin{array}{l}\text { Nusapati } \\
\text { (2016) }\end{array}$ & - & $\begin{array}{l}1 \text { people } \\
\text { killed }\end{array}$ \\
\hline $\begin{array}{l}\text { Peniraman } \\
(2010)\end{array}$ & $\begin{array}{l}5 \text { houses severely } \\
\text { damaged, } 1 \text { house } \\
\text { was slightly } \\
\text { damaged, } 18 \text { houses } \\
\text { were submerged }\end{array}$ & - \\
\hline $\begin{array}{l}\text { Peniraman } \\
(2017)\end{array}$ & - & - \\
\hline
\end{tabular}


Source: BPBD Mempawah Regency \& Borneo Tribun Mempawah 2017

Based on the landslide data above shows that Sungai Pinyuh District is an area that is prone to landslides, which is indicated by the occurrence of landslides in Peniraman and Nusapati villages that have occurred and caused loss and casualties. So that the area is very cautious, especially when entering the month with high rainfall intensity.Besides natural factors, the landslide occurred due to community activities. According to the sub- district head, Sungai Pinyuh District obtained from observations, the community is expected to be able to utilize and manage the land well, one of which is not to over-exploit the hilly land.

According to the Regional Disaster Management Agency (BPBD) there are stillseveral villages in Sungai Pinyuh subdistrict are prone to landslides, but the potential level of vulnerability to landslide hazards in each village cannot be known with certainty, because at this time the government institution especially the Regional Disaster Management Agency (BPBD) has not provided maps of landslide vulnerability in coverage regencies or sub-districts, which are currently only available, in general, maps of disaster vulnerability for district coverage that provide information related to the distribution of disasters in the form of floods, landslides and land fires in Mempawah District, so it is necessary to have landslide hazard maps for the coverage of Sungai Pinyuh District which can be input for the community, government, education and other relevant stakeholders.

Based on the background of the above research, it is necessary to do a mapping of potential landslides in Sungai Pinyuh District, with the title: "Identification of Landslide Prone Areas and Management in Sungai Pinyuh District of Mempawah Regency". This research becomes necessary and important to do in order to provide information on the distribution of landslide-prone areas based on the level of vulnerability to landslide hazards that can be used as a reference in making efforts to prevent landslides in Sungai Pinyuh District.

\section{B. MATERIALS AND METHODS}

This research was conducted in Sungai Pinyuh Subdistrict, which included 9 villages in Sungai Pinyuh Subdistrict, namely: Sungai Purun Kecil Village, Peniraman, Nusapati, Galang, Sungai Rasau, Sungai Pinyuh, Sungai Batang, Sungai Bakau Besar Laut and Sungai Bakau Besar Darat Village. 
This type of research used in this study is a qualitative study, by carrying out secondary data weighting / observation and primary data observation. The research method used in this study is the overlay method (overlapping maps) with quantitative tiered weighted overlay modeling and descriptive analysis of the results of field observational surveys.

Data collection techniques used in this study were carried out by observing primary data (related to the physical condition data of land characteristics at selected points which included: soil color data, geological conditions, landforms and land use), and documentation carried out to obtain secondary data.

The data used in this study, in the form of map data (shp) from several maps, namely: administrative maps, slope maps, landform maps, rainfall maps, geological maps, maps of soil types and maps of land use in Mempawah Regency. The initial process of data processing includes map scanning, coordinate correction, digitization on screen, attribute, process and output. symbols. Then look at the area distribution specifications, whether included in the regular area distribution patterns, random area distribution patterns or included in the clustered area distribution pattern specifications.

Data processing and analysis were carried out to determine the spatial extent of hazard distribution in Sungai Pinyuh Subdistrict, with a weighted tiered quantitative overlay modeling. Weighted tiered quantitative approach is an approach that determines each unit in one theme has a value or value that is adjusted to the contribution or influence on the determination of the results and the model. The classification is done based on certain classes, namely as many as (5) classes on each parameter. The assignment of weight values is done differently from each parameter according to the level of influence on the potential for landslides. The weighting classification of each parameter used, namely: 
Table 2. Parameter of Landslide Hazard Rate in Sungai Piyuh District

\begin{tabular}{|c|c|c|c|c|c|c|}
\hline Parameter & Information & Quality & Value & $\begin{array}{c}\text { Score } \\
\text { (B X H) }\end{array}$ & Score Min & Score Max \\
\hline KL & $\begin{array}{l}\text { - Flat } \\
\text { - Sloping }(8 \%-15 \%) \\
\text { - Rather Steep } \\
\text { - Steep } \\
\text { - Verry Step } \\
\end{array}$ & 5 & $\begin{array}{l}1 \\
2 \\
3 \\
4 \\
5\end{array}$ & $\begin{array}{c}5 \\
10 \\
15 \\
20 \\
25\end{array}$ & 5 & 25 \\
\hline $\mathrm{BL}$ & $\begin{array}{l}\text { - Tidal Land, Swamps } \\
\text { Beaches } \\
\text { - Alluvial Land } \\
\text { - Volkan Plains, } \\
\text { Volcanic Slopes, } \\
\text { Corrugated Plains, } \\
\text { Hilly Slopes, Slopes } \\
\text { Midle, Plains Between } \\
\text { plains. } \\
\text { - Mountain, Hills } \\
\text { - Cone }\end{array}$ & 4 & $\begin{array}{l}1 \\
2\end{array}$ & $\begin{array}{l}12 \\
\\
16 \\
20\end{array}$ & 4 & 20 \\
\hline $\mathrm{CH}$ & $\begin{array}{l}\text { - Very Low }(<1500) \\
\text { - Low }(1500-1.800) \\
\text { - Medium }(1.800-2.100) \\
\text { - Height }(2.100-2400) \\
\text { - Very High }(>2400)\end{array}$ & 4 & $\begin{array}{l}1 \\
2 \\
3 \\
4 \\
5\end{array}$ & $\begin{array}{c}4 \\
8 \\
12 \\
16 \\
20\end{array}$ & 4 & 20 \\
\hline FG & $\begin{array}{l}\text { - Aluvial Materialals } \\
\text { (Qav,Qat,Qa,Qc) } \\
\text { - Volcanic-1 (Qvu,Qvep, } \\
\text { Qvk, } \\
\text { Qvba,Toms) } \\
\text { - Sidiment-1 } \\
\text { (Tmn,Tmj,Toh) } \\
\text { - Sidement-2 (Klr) } \\
\text { - Vulkanik-2 (Klm) }\end{array}$ & 3 & $\begin{array}{l}3 \\
4 \\
5\end{array}$ & $\begin{array}{r}3 \\
6 \\
6 \\
9 \\
12 \\
15\end{array}$ & 3 & 15 \\
\hline \multirow[t]{2}{*}{ JT } & $\begin{array}{l}\text { - Aluvia, glei planasol } \\
\text { land, hidromoft gray, } \\
\text { literary groundwater } \\
\text { (No Sensitive) } \\
\text { - Latosol (insensitive) } \\
\text { - Brown Forest Soil, } \\
\text { Non Calcis Brown, } \\
\text { Mediteran (Somewhat } \\
\text { Sensitive } \\
\text { - Andosol, Laterit, } \\
\text { Gramusol,Podsol, } \\
\text { Podsolik Sensitive } \\
\text { - Litosol Organosol, } \\
\text { Renzima(Very } \\
\text { Sensitive }\end{array}$ & 2 & $\begin{array}{l}1 \\
2 \\
3\end{array}$ & $\begin{array}{c}2 \\
4 \\
12\end{array}$ & 2 & 10 \\
\hline & $\begin{array}{l}\text { - Rivers, forests, } \\
\text { reservoirs, irigated } \\
\text { fields, swamps in flat } \\
\text { areas, mangroves, }\end{array}$ & & 1 & 2 & 2 & 10 \\
\hline
\end{tabular}




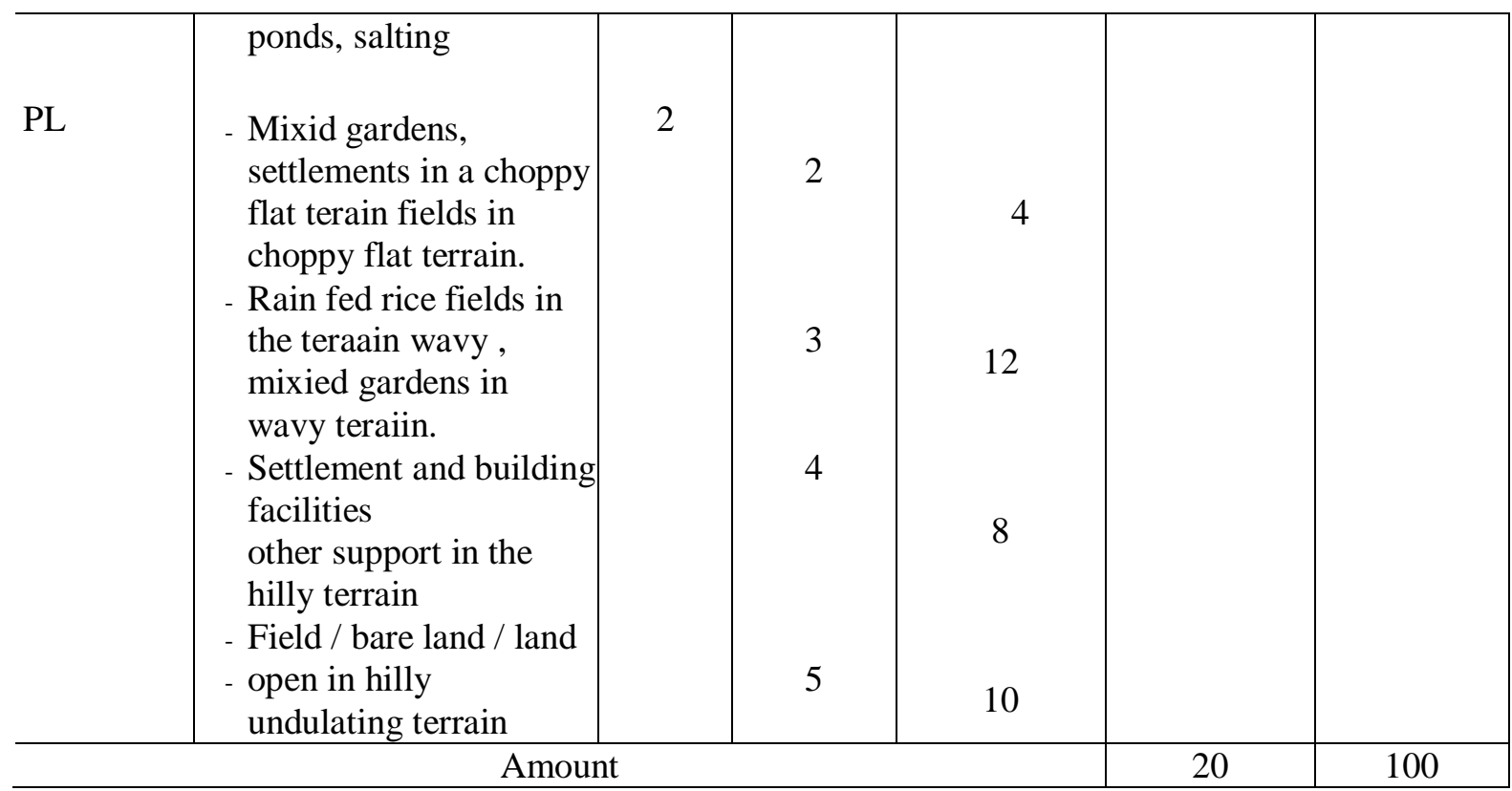

Source: Pusat Studi Bencana Alam dan Modifikasi Penulis Information

From the table above shows there are 6 parameters that are used as determinants of class classification of landslide prone levels. Calculation of Class Interval refers to Dibyosaputro (in Hermon, 2012: 42) with the calculation of the class interval formula, as follows:

$$
I=\frac{C-B}{k}
$$

Description of the formula above:

I : Large interval class

B : The lowest number of scores

$\mathrm{C}$ : The lowest number of scores

$\mathrm{K}$ : Number of Classes wanted (3 classes)

Based on the equation above, each interval class size is: 26,7. As for the classification of landslide vulnerabilitty levels consist of:

Table 3. Classification of Landslide Hazard Level

\begin{tabular}{ccc}
\hline Number & Interval Class & Landslide Hazard Rate \\
\hline 1 & $26,7-53,4$ & Low (Not Prone) \\
\hline 2 & $53,4-80,1$ & Medium (Prone) \\
\hline 3 & $>80,1$ & High (Very Vulnerable)
\end{tabular}

Source: Hermon (2012:42)

C. RESULTS AND DISCUSSION

\section{Spatial Distribution Rate of}

Landslide Hazard in Sungai Pinyuh

District of Mempawah Regency. 
MAP OF LANDSLIDE VULNERABILLITY IN SUNGAI PINYUH SUB-DISTRICT OF MEMPAWAH REGENCY

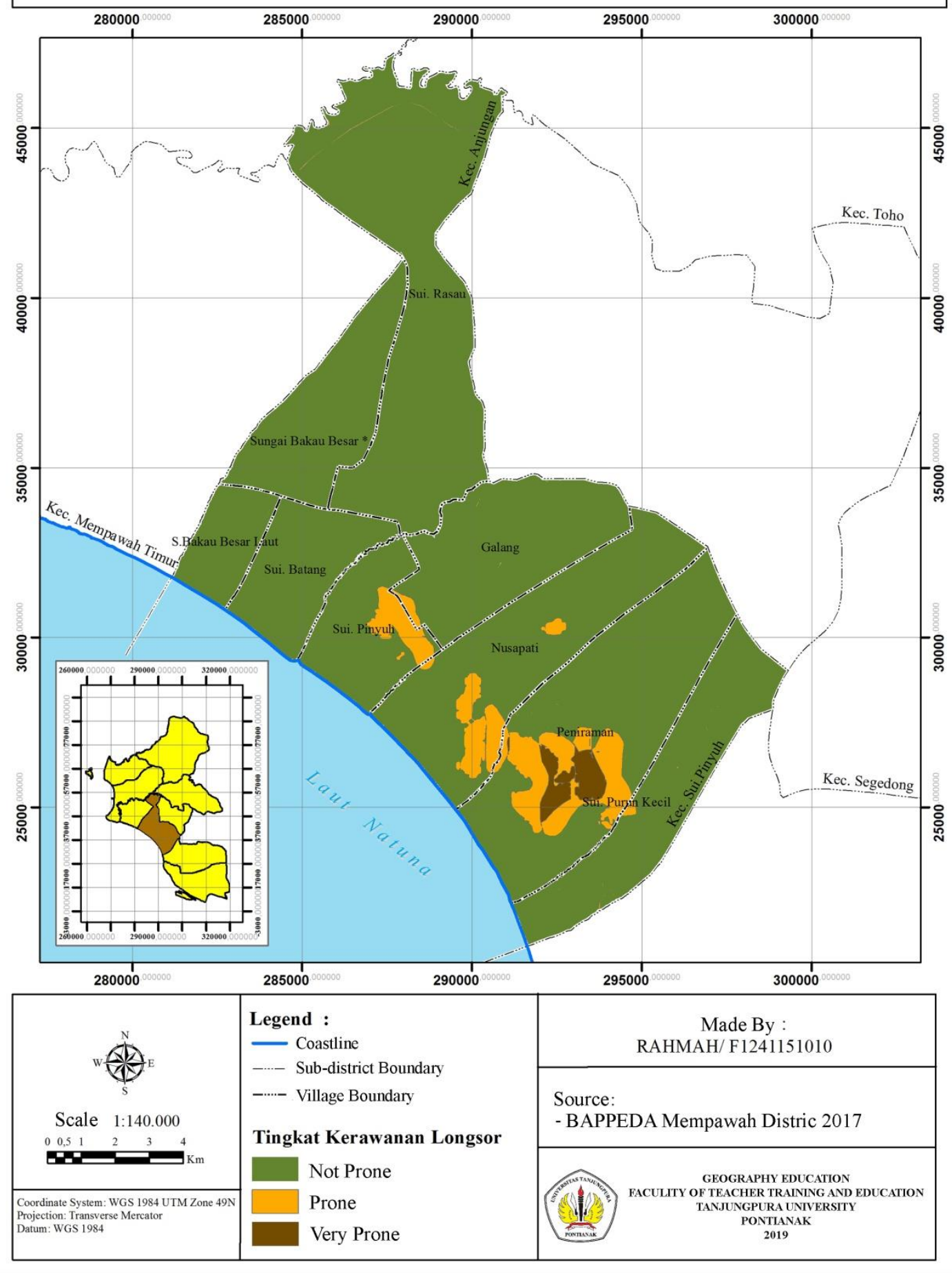

Figure 1. Landslide Hazard Level Map Source: Researchers, 2019 
Table 4. Landslide Hazard Level Spatial Distribution in Sungai Pinyuh Sub-District

\begin{tabular}{|c|c|c|c|}
\hline Village & Landslide Hazard Rate & $\begin{array}{l}\text { Large } \\
(\mathrm{Ha})\end{array}$ & $\begin{array}{c}\text { Persentase } \\
(\%)\end{array}$ \\
\hline \multirow{3}{*}{$\begin{array}{l}\text { Desa } \\
\text { Sungai } \\
\text { Purun Kecil }\end{array}$} & Low (Not Prone) & 1910 & 9,84 \\
\hline & Medium (Prone) & 22 & 0,11 \\
\hline & $\begin{array}{l}\text { High (Very } \\
\text { vulnerable) }\end{array}$ & 0 & 0,00 \\
\hline \multirow{3}{*}{ Peniraman } & Low (Not Prone) & 2795 & 14,39 \\
\hline & Medium (Prone) & 625 & 3,22 \\
\hline & $\begin{array}{l}\text { High (Very } \\
\text { vulnerable) }\end{array}$ & 223 & 1,15 \\
\hline \multirow{3}{*}{ Nusapati } & Low (Not Prone) & 2413 & 12,43 \\
\hline & Medium (Prone) & 337 & 1,74 \\
\hline & $\begin{array}{l}\text { High (Very } \\
\text { vulnerable) }\end{array}$ & 0 & 0,00 \\
\hline \multirow{3}{*}{ Galang } & Low (Not Prone) & 1956 & 10,07 \\
\hline & Medium (Prone) & 46 & 0,24 \\
\hline & $\begin{array}{l}\text { High (Very } \\
\text { vulnerable) }\end{array}$ & 0 & 0,00 \\
\hline \multirow{3}{*}{$\begin{array}{l}\text { Sungai } \\
\text { Rasau }\end{array}$} & Low (Not Prone) & 4488 & 23,11 \\
\hline & Medium (Prone) & 0 & 0,00 \\
\hline & $\begin{array}{l}\text { High (Very } \\
\text { vulnerable) }\end{array}$ & 0 & 0,00 \\
\hline \multirow{3}{*}{$\begin{array}{l}\text { Sungai } \\
\text { Pinyuh }\end{array}$} & Low (Not Prone) & 945 & 4,87 \\
\hline & Medium (Prone) & 229 & 1,18 \\
\hline & $\begin{array}{l}\text { High (Very } \\
\text { vulnerable) }\end{array}$ & 0 & 0,00 \\
\hline \multirow{3}{*}{$\begin{array}{l}\text { Sungai } \\
\text { Batang }\end{array}$} & Low (Not Prone) & 1172 & 6,04 \\
\hline & Medium (Prone) & 0 & 0,00 \\
\hline & $\begin{array}{l}\text { High (Very } \\
\text { vulnerable) }\end{array}$ & 0 & 0,00 \\
\hline \multirow{3}{*}{$\begin{array}{l}\text { Sungai } \\
\text { Bakau } \\
\text { Besar } \\
\text { Laut }\end{array}$} & Low (Not Prone) & 653 & 3,36 \\
\hline & Medium (Prone) & 0 & 0,00 \\
\hline & $\begin{array}{l}\text { High (Very } \\
\text { vulnerable) }\end{array}$ & 0 & 0,00 \\
\hline \multirow{4}{*}{$\begin{array}{l}\text { Sungai } \\
\text { Bakau } \\
\text { Besar } \\
\text { Darat }\end{array}$} & Low (Not Prone) & 1604 & 8,26 \\
\hline & Medium (Prone) & 0 & 0,00 \\
\hline & $\begin{array}{l}\text { High (Very } \\
\text { vulnerable) }\end{array}$ & 0 & 0,00 \\
\hline & Total & 19418 & 100 \\
\hline
\end{tabular}

Based on the attribute data that contains the classification of landslide hazard levels in Sungai Pinyuh District, there are 3 (three) levels of landslide vulnerability, namely: a) Low Succeptibility (Not Prone)

This area has a low level of vulnerability, which is an area that is not prone to landslides. In Sungai Pinyuh District, areas that are not prone to landslides are found in all villages in Sungai Pinyuh District, namely: Galang Village, Nusapati Village, Peniraman Village, Bakau Bear Laut Village, Sungai Batang Village, Sungai Pinyuh Village, Sungai Purun Kecil Village, Sungai Sungai Village Rasau, and Sungai Bakau Besar Darat Village. The area with the lowest level of vulnerability (not prone) is the largest in Sungai Rasau Village with an area of 4488 ha or $23.11 \%$ of the area of Sungai Pinyuh Sub-district.

b) Moderate Susceptibility (Prone)

This area has a moderate level of vulnerability, which is an area that is potentially vulnerable to landslides. In Sungai Pinyuh District, vulnerable areas are found in 5 (five) villages in Sungai Pinyuh District, namely: Galang Village, Nusapati Village, Peniraman Village, Sungai Pinyuh Village, and Sungai Purun Kecil Village. 
The area with the highest level of vulnerability (vulnerable) is found in Peniraman Village with an area of 625 ha or $3.22 \%$ of the area of Sungai Pinyuh Subdistrict.

c) High vulnerability (very vulnerable)

This area has a high level of vulnerability, which is an area that is potentially very vulnerable to landslides. In Sungai Pinyuh Subdistrict, areas that are very prone to landslides are only found in Peniraman Village, which has 223 ha or $1.15 \%$ of the total area of Sungai Pinyuh Sub-district.

\section{Based on The Level of Landslide} Hazard in Sungai Pinyuh SubDistrict.

Based on the map of observation points of landslide-prone areas in Sungai Pinyuh Subdistrict, it shows 7 (seven) points of observation locations in areas with potential landslide-prone areas in Sungai Pinyuh District. In general, the condition of the 6 (six) observation locations is an area with high potential to experience landslides, but in areas with moderate levels of vulnerability (prone) there are no settlements, as well as construction of buildings that are threatened relatively inexpensive or important. The potential for landslides is caused by improper land use and management, such as improper land use and excavation of $\mathrm{c}$ mining materials and rock mining, which causes reduced vegetation cover that affects slope stability, which can trigger landslides.

Areas with a high level of vulnerability (very vulnerable) are areas with high potential to experience landslides, and there are dense settlements, and construction of buildings is very expensive or important, and in this area, landslides often occur, especially during the rainy season arrived .. The potential for landslides due to landforms in the form of steep hills with steep slope conditions. in this area there is open land which is not covered by vegetation in the middle of the slope, visible soil material and hanging rocks, located close to residential areas. Thus, this area is very wary of during the rainy season, and not infrequently many residents who live under the slope, choose to leave their homes when the rainy season arrives.

Based on the results of the analysis of landslide hazard level maps in figure 1, 
it can be seen that the spatial distribution of landslide potential areas in Sungai Pinyuh District of Mempawah Regency, shows the category of moderate (vulnerable) and high (very vulnerable), with the distribution pattern of clustered areas . As for the distribution of landslide areas with the category of vulnerable spread in groups in five villages, namely: Galang Village, Nusapati Village, Peniraman Village, Sungai Pinyuh Village, and Sungai Purun Kecil Village, while for areas with a very vulnerable category are only found in Peniraman Village.

The distribution (distribution) of landslide-prone areas that form a clustered area pattern is formed because the five villages have hilly land forms with different slope rates. Areas with vulnerable categories are areas dominated by landforms in the form of undulating terrain with slope of $9-15 \%$ to $16-25 \%$, while for very vulnerable categories are steep hills with slope of $26-45 \%$. Thus, it can be seen that differences in landform conditions and slope are very influential on the distribution (distribution) of landslide- prone areas. The results of the analysis show that there are 6 locations of areas with moderate levels of vulnerability (hazard) and1 location of areas with high degree of vulnerability (very vulnerable). Then, the researchers made observations to 7 locations of the landslide prone areas. From observations it is known, the level of landslide prone is supported by the parameters of the menibau grandiorite geological formation, which is a type of formation that is mostly found in the hills of Sungai Pinyuh District, besides the level of vulnerability is also influenced by the type of soil. Soil types in Sungai Pinyuh Subdistrict consist of two types of soil namely, peat soils and alluvial soils. Alluvial soil types have a texture that is generally loamy clay with fine sand. For this type of soil sensitive to landslides, while organosol soil is land that is often found on the slopes to the bottom of the slope. For the average annual rainfall, areas with vulnerability are not prone, prone and very vulnerable, have the intensity of rainfall that is relatively equal / average, that is $2750 \mathrm{~mm}$ / year.

For land use parameters that trigger landslides are plantations, rice fields, and settlements. In locations prone to landslides, there are many cultivated plantations such as cassava, banana, and sahang. This type of vegetation has roots that are not strong enough to resist landslides. In addition, the potential for landslides is also influenced by human activities such as the presence of rock mining activities and $\mathrm{C}$ mining activities 
that cause damage and loss of vegetation that has strong roots, as a cover slope.

The results of this study, as well as one of the relevant studies conducted by Ahmad Danil Efendi on the identification of landslide events and the determination of the main factors causing them in Bababkan Madang District, Bogor Regency. In his research, Babakan Madang Subdistrict included in the level of landslide vulnerability category prone. Many plantations are also found in the highlands that are not planted with strong root trees. In addition, it is the same as the Pinyuh River District, where in the Babakan Madang District there is a potential for landslides caused by human activities in the form of cutting slopes.

In addition, there are areas with very vulnerable categories in Sungai Pinyuh District, because these areas have steep landforms and steep slopes, and there are former landslides and are supported by very high rainfall conditions. Thus, it can be concluded that landslide prone areas with steep slope conditions and land forms in the form of moderate to steep hills, and supported by the presence of landslides can be a trigger that the area has a very high level of vulnerability.

Therefore, based on the explanation above, it is necessary to take preventive measures in the form of appropriate preventive measures, as an effort to minimize the danger of landslides. In this research prevention efforts that will be recommended refer to the guidelines for the preparation of disaster management plans \& BAKORNAS PB.

The general recommendations that researchers can arrange in compiling prevention efforts at the seven selected points in Sungai Pinyuh District Mempawah Regency are: Do not cut down trees on the slope, because tree roots are very useful for making the soil structure stronger, with its ability to absorb water and store it in the ground, so that it can reduce ground water flowing and damage the soil structure that triggers landslides. Do not cut the cliff perpendicularly, making building structures that function to prevent, secure and reduce the impact caused byat the bottom of the slope, and making and placing warning signs, danger, prohibition from entering landslide prone areas.

Can be concluded that the difference in the level of landslide vulnerability in landslide prone areas, will affect the size of the potential for landslides, which can be supported by conditions of land charateristics in the landslide-prone areas. So it is important to know the distribution (distribution) of landslide-prone areas that contain information onthe level of landslide 
vulnerability in an area, especially in

Sungai Pinyuh District. To find out more about prevention efforts can be seen in figure 2 .
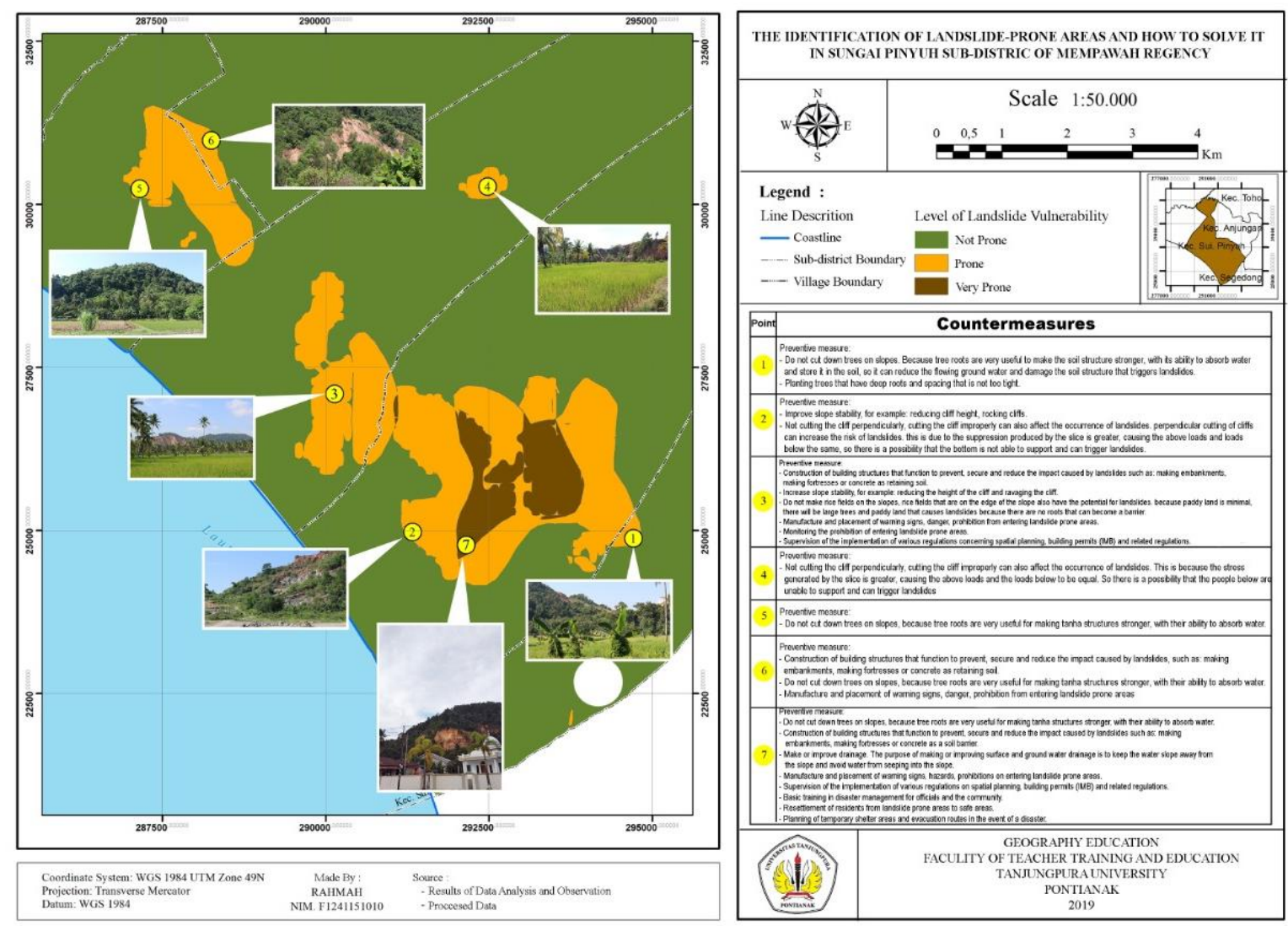

Figure 2. Mitigation Map Based on the level of Lanslide Hazard in Sungai Subdistrict Source: Researchers, 2019

\section{CONCLUSIONS}

Based on research and analysis, the following conclusions can bedrawn: (1) Spatial distribution of potential landslides in Sungai Pinyuh Subdistrict of Mempawah Regency, forming a pattern of distribution of clustered areas. The distribution of landslide potential areas in Sungai Pinyuh District consistsof 3 categories: not prone, moderate (vulnerable) and high (veryvulnerable). The area with moderate level of vulnerability (vulnerable) has an area of 1259 ha spread in groups in fivevillages, namely: Galang Village, Nusapati Village, Peniraman Village, SungaI PinyuhVillage, and Sungai Purun Kecil Village, while for areas with high levels of vulnerability (veryvulnerable) has an area of 223 ha, whic his only found in Peniraman Village, and for areas with no potential / landslide prone area of 17,936 ha. (2) Counter measures are determinedat the selected point of there sults of the determination of 
areas with potential landslides, by compiling pre- disaster prevention measures, which are focused on areaswith a level of vulnerability (vulnerable and veryvulnerable) as well as observation susing parameters of land use type as a reference in determining appropriate prevention efforts.

\section{E. REFERENCES}

Anandan. (2008). Maaping and Mitigasi of Geohazards in Mountains Using Remote Sensing and GIS. Tesis. India: University Tiruchirappalli.

Beaty. (2017). Longsor Active Detection A Geospatial Approach. Journal. South India.
Hermon, Dedi. (2012). Geografi Bencana Alam. Jakarta: Rajawali Press.

Muthukumar. (2017). Optimization Method For Mapping Soil Vulnerability Using Geospatial and Geostitical Tools. Journal. India.

Guillard, Clemence. (2016). Vulnerability Assessment and Landslide Risk Analysis Aplication to The Loures Municipality Portugal. Tesis. Portugal: ULISBO.

FAO (Food and Agriculture Organization). (2011). Forests and Landslides (the role of tress and forests in the prevention of lindslides and rehabilitation of landslide-affected areas in Asia). Thailand: RAP Publication.

Sutikno. (2002). Sistem Informasi Penanggulangan Bencana Alam Tanah Longsor. Yogyakarta: BPFG UGM. 